Crônicas de direito internacional ............................................................. Julia Motte-Baumvol e Alice Rocha da Silva

BRAZILIAN TRADE POLICY IN HISTORICAL PERSPECTIVE: CONSTANT FEATURES, ERRATIC BEHAVIOR..11 Paulo Roberto de Almeida

Aspectos GEopolíticos do GAT'T E DA OMC .........................................................28 José Fontoura Costa

A REgulaÇÃo INTERNACIONAL dos SUbSídios AGRÍCOLAS: A CONTEMPORANEIDADE DO PARADIGMA REALISTA PARA A COMPREENSÃO DO SISTEMA DE COMÉRCIO AGRÍCOLA INTERNACIONAL VIGENTE

Natália Fernanda Gomes

ACORDO TRIPS: ONE-SIZE-FITS-ALL?

Tatianna Mello Pereira da Silva

É INTERESSANTE PARA O BRASIL ADERIR AO ACORDO SOBRE COMPRAS GOVERNAMENTAIS DA OMC?

Clarissa Chagas Sanches Monassa e Aubrey de Oliveira Leonelli

A Defesa COMERCIAL E A RESTRIÇÃo dA LIBERALIZAÇÃo E DA INTEGRAÇÃo COMERCIAL PELO AUMENTO DA ALÍQUOTA DE IPI DE VEÍCULOS IMPORTADOS NO BRASIL...................................86

Ricardo Serrano Osorio e Clayton Couto

A COOPERAÇÃo INTERNACIONAL NA DEFESA DA CONCORRÊNCIA

Vinicius Marques de Carvalho e Paulo Burnier da Silveira

Os ACORDOS DE COMÉRCIO PARA ALÉM DAS PREFERÊNCIAS: UMA ANÁLISE DA REGULAMENTAÇÃO SOBRE OS "NOVOS TEMAS" 105

Michelle Ratton Sanchez Badin e Lucas da Silva Tasquetto

INTEGRAÇÃO ECONÔMICA NO MERCOSUL: OPINIÕES CONSULTIVAS E A DEMOCRATIZAÇÃO NO ACESSO AO TRIBUNAL PERMANTE DE REVISÃO 128 Eduardo Biachi Gomes

"Fundos abutres" vs. Estados NaCionais: SObERANiA E ATUAÇÃo do Tribunal INTERNACIONAL do Direito do Mar a partir do Caso da Fragata libertad.. 138 Alexandre Pereira da Silva e Mariana Yante Barrêto Pereira

INVESTIMENTO ESTRANGEIRO: O PADRÃO DE TRATAMENTO JUSTO E EQUITATIVO E O PAPEL DA BOA-FÉ 
Fernando Santos Arenhart

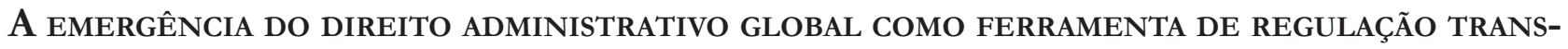
NACIONAL DO INVESTIMENTO ESTRANGEIRO DIRETO .................................................. 171

Andréa Rocha Postiga

Is INVESTMENT ARBITRATION AN APPROPRIATE VENUE FOR ENVIRONMENTAL ISSUES? A LATIN AMERICAN PERSPECTIVE.

Nitish Monebhurrun

A jurisprudência do Superior Tribunal de Justiça e a construção de um Conceito de

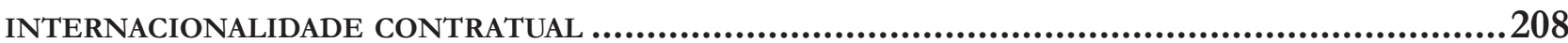

Frederico E. Z. Glitz

IMPACTO E INFLUÊNCIA DOS TRATADOS E CONVENÇÕES INTERNACIONAIS SOBRE A LEI BRASILEIRA DE ARBITRAGEM

Jamile Bergamaschine Mata Diz e Clarissa Correa Neto Ribeiro

A JURISPRUdÊNCIA NORTEAMERICANA E EUROPEIA SOBRE OS ACORDOS HORIZONTAIS E VERTICAIS: SUBSTRATO PARA ANÁLISE DA MATÉRIA NO BRASIL.

Daniel Amin Ferraz 


\title{
Is investment arbitration an appropriate venue for environmental issues? A Latin American perspective.
}

\author{
As arbitragens sobre investimentos são \\ apropriadas para tratar temas ambientais? \\ Uma perspectiva latino-americana*
}

\begin{abstract}
The aim of this contribution is to examine how the environmental conundrums are brought before arbitral tribunals within the ambit of international investment law. It seeks to understand whether these tribunals specialised in investment law constitute an appropriate forum to consider environmental issues. The method applied is an inductive one. The general argumentation is indeed induced from the study of the awards rendered by arbitral tribunals, mainly within the Latin-American region. In this vein, the article concludes that although investment tribunals are not primarily designated to apply environmental law, they do, practically, accept environment protection arguments: this will be presented as an "environmental defense". The article highlights the conditions for such a defense to be successful. For this reason, the contribution has a practical value: instead of focusing on the protection of the environment as a mere objective - as it is often done -, it presents such a protection as a means of defense in arbitral litigations.
\end{abstract}

Keywords: International investment law, international arbitration, environmental law

\section{Resumo}

O objetivo desta contribuição é examinar como as problemáticas ambientais são levadas perante os tribunais arbitrais, no âmbito do direito internacional dos investimentos. Pretende-se compreender se estes tribunais especializados em direito dos investimentos constituem um fórum apropriado para tratar de questões ambientais. O método utilizado para tanto é indutivo. A argumentação geral é induzida a partir do estudo das sentenças proferidas por tribunais arbitrais, principalmente na região latino-americana. Nesse sentido, o artigo conclui que, embora os tribunais arbitrais não sejam principalmente designados para aplicar o direito ambiental, estes aceitam, na prática, a proteção do meio ambiente como um argumento válido, e isto será apresentado como uma "defesa ambiental" na arbitragem. O artigo destaca as condições para garantir o sucesso dessa defesa. Por esta razão, a contribuição tem um valor prático: em vez de considerar a proteção do meio ambiente como um mero objetivo, como é habitualmente feito, esta será apresentada como um meio de defesa em litígios arbitrais.
1 The author is a United Nations (UNDP) consultant at the Conselho Administrativo de Defesa Econômica of Brazil and a Ph.D Fellow at the Law School of Sorbonne, Paris. Email: nitish.monebhurrun@gmail.com

* Recebido em 24/10/2012

Aprovado em 26/01/2013 


\section{INTRODUCTION}

Scope of the study ${ }^{2}$. Many Latin American States have always had a tumultuous relationship with international investment law ${ }^{3}$. However, despite a surely unconscious Calvo heritage distilled in their mindset, they remain strong and important actors of this law field ${ }^{4}$. In view of this Biennial Conference of the Latin American Society of International Law, it is on the Latin American background that this article will consider to what extent investment arbitration is an appropriate venue for environmental questions. At the same time, the present contribution will try to abide to the Conference's theme which is, 'Heritage and Inheritance in International Law'. The logic of 'heritage and inheritance' used here will be that of stock taking: past interactions between investment law and environmental protection will be highlighted in order to provide a reading grid of some techniques which can eventually be applied by Latin American States should they - as some of them have been - be confronted to cases implying similar conundrums. These techniques are not absolute ones. They are available possibilities with specific principles which can, however, be adapted for the sake of other cases. Obeying to the Conference's settings in which writing space and time accorded for the presentation are both limited, the study will obviously not be exhaustive ${ }^{5}$.

\footnotetext{
2 This article was accepted for and presented at the Latin-American Society of International law biennial conference in August 2012 in Rio de Janeiro, Brazil.

3 RANCK, Suzanne. Development and outcome of investment treaty arbitration. Harvard International Law Journal, v. 50, n. 2, p. 202, 2009.; GAILLARD, Emmanuel. Anti-arbitration trends in Latin America, New York Law Journal, v. 239, n. 108, 5 jun. 2008.; GARCIA-BOLIVAR, Omar E. The surge of investment disputes: Latin America testing the international law of foreign investments. In: THE SECOND BIENNIAL GENERAL CONFERENCE OF THE ASIAN SOCIETY OF INTERNATIONAL LAW, TOkyo, aug. 2009. Annals... p. 4-6. Tokyo: University of Tokyo, 2009.; FACH GOMEZ, Katia. Latin America and ICSID: David versus Goliath. Law and Business Review of the Americas, v. 17, p. 216-221, 2011; MACHADO, Decio. Ecuador y la denuncia de los tratados bilaterales de inversión, CATDM, 07/12/2009. Available at: <http:// www.cadtm.org/ Ecuador-y-la-denuncia-de-los $>$.

4 MORTIMORE, Michel, STANLEY, Leonardo. Justice denied: dispute settlement in latin america's trade and investment agreements, working group on development and environment in the Americas. Discussion Paper, n. 27, p. 2, oct. 2009.

5 Some studies have shed a deeper and more global light on the subject. See: ROBERT-CUENDET Sabrina. Protection de l'environnement et investissement étranger: les règles applicables à la dépossession du fait de la réglementation environnementale. Paris: Thèse, 2008. p. 530.; VIÑUALES, Jorge. Foreign investment and the environment in international law: an ambiguous relationship.
}

Components of 'Environment'. 'Environment' will here be taken in its lato sensu sense, that is, encompassing natural ressources like air, water, soil, fauna and flora but also cultural heritage. This method to identify what pertains to environment is not purely subjective. The Lugano Convention on Civil Liability for Damage Resulting from Activities Dangerous to the Environment of the 21 th June 1993 reveals a similar definition ${ }^{6}$ which also happens to be that of the United Nations Environment Program ${ }^{7}$. These components of the definition of the concept of environment are protected by a whole network of international environmental agreements ${ }^{8}$. Still, this does not mean that environmental questions and issues are limited and restricted to the

Research Paper, Geneva, n. 2, p. 1-74, 2010.

6 Lugano Convention on Civil Liability for Damage Resulting from Activities Dangerous to the Environment, 21 June 1993, article 2.12 Available at: http://conventions.coe.int/treaty/fr/Treaties/Html/150.htm).

FITZMAURICE, Malgosia. International protection of the environment, R.C.A.D.I.,v. 293, p. 25, 2001.

8 See for example: United Nations Framework Convention on Climate Change, 9/05/1992; United Nations Convention on Biodiversity, 05/06/1992; Helsinki Convention on ransboundary Watercourses and International Lakes, 17/03/1992; Convention for the Protection of the Marine Environment of the North-East Atlantic, 22/09/1992; Convention for the Conservation of Southern Bluefin Tuna, 10/05/1993; Convention on the Cooperation for the Protection and Sustainable use of the Danube River, 29/06/1994; United Nations Convention to Combat Desertification in Those Countries Experiencing Serious Drought and/or Desertification, Particularly in Africa, 14/10/1994; Protocol Concerning Specially Protected Areas and Biological Diversity in the Mediterranean, 10/06/1995; Agreement on the Cooperation for the Sustainable Development of the Mekong River bassin, 05/04/1995; Convention for the Protection of the Marine Environment and the Coastal Region of the Mediterranean, 10/06/1995; Kyoto Protocol to the United Nations Framework Convention on Climate Change, 11/12/1997; Rotterdam Convention on the Prior Informed Consent Procedure for Certain Hazardous Chemicals and Pesticides in International Trade, 10/09/1998; Cartagena Protocol to the United Nations Convention on Biodiversity, 29/01/2000; European Landscape Convention, 20/10/2000; Convention on the Conservation and Management of Fihsery Ressources in the South-East Atlantic Ocean, 20/04/2001; Stockholm Convention on Persistent Organic Pollutants, 22/05/2001; Black Sea Biodiversity and Landscape Conservation Protocol to the Convention on the Protection of the Black Sea against Pollution, 14/06/2002; Convention for Cooperation in the Protection and Sustainable Development of the Marine and Coastal Environment of the Northeast Pacific, 18/02/2002; ASEAN Agreement on Transboundary Haze Pollution, 10/06/2002; Convention on Strategic Environmental Assessments to the convention on Environmental Impact Assessment in a Transboundary Context, 21/05/2003; Convention on the Conservation and Management of Highly Migratory Fish Stocks in the Wstern and central Pacific Ocean, 19/06/2004; Treaty on the conservation and sustainable management of Forest Ecosystems in Central Africa and to Establish the Central African Forests Commission, 05/02/2005; Charter of the Association of South-East Asian Nations, 20/11/2007. 
sole ambit of national or international environmental law.

Two levels where international investment law and environmental protection meet. Environmental questions, claims or damages are seldom standalone ones. Very often, an environmental question will not be only and purely related to the environmental law ambit? Practically, such questions may arise in the context of economic law, of administrative law, of sea law or of human rights. It is in the same vein that environmental issues have been colouring the framework of international investment law ${ }^{10}$. This can be illustrated at two levels. Firstly, there have been some investment cases triggered after the adoption by a State, of an environment protection measure. Foreign investors have claimed that such measures adopted by their host States were in violation of their protected rights under an applicable investment agreement ${ }^{11}$. The investors claimed that the enforcement of an environmental measure had a detrimental effect on their activities. The roots of environmental law have reached the field of international investment law, thereby setting up a scene with interweaving nor$\mathrm{ms}$, often in a disorderly fashion and with a degree of interaction worth studying ${ }^{12}$. Secondly, and in the same

\footnotetext{
9 SANDS, Philippe. Litigating environmental disputes: courts, tribunals and the progressive development of international environmental law: the policy framework for investment: the social and environmental dimensions, Global Forum on International Investment, OECD, p. 4, mar. 2008.

10 TIENHAARA, Kyla. Unilateral commitments to investment protection: does the promise of stability restrict environmental policy development?, Yearbook of International Environmental Law, v. 17, p. 139, 2006.

11 See for example: Compañia del Desarrollo de Santa Elena, S.A., v. Costa Rica, ICSID Case No.ARB/96/1, Final Award, 17/02/2000; Metalclad Corporation v. Mexico, ICSID n ${ }^{\circ}$ ARB/AF/97/1, award, (30/08/2000); Técnicas Medioambientales Tecmed, S. A. v. Mexico, ICSID $\left.\mathrm{n}^{\circ} \mathrm{ARB}(\mathrm{AF}) / 00 / 2\right)$, Award (29/05/2003); MTD Equity $S d n$. Bhd. \& MTD Chile S.A. v. Chile, ICSID n . ARB/01/7, Award (25/05/04); Southern Pacific Properties (Middle East) Ltd v. Egypt, ICSID $n^{\circ}$.ARB/84/3, Award (20/05/1992); Parkerings-Compagniet AS v. Lithuania, ICSID n . ARB/05/8, Award (11/09/07); SD Myers v. Canada, UNCITRAL, Partial Award (13/12/2000); Etbyl Corp. \& Canada Ethyl Corp. v. Government of Canada, UNCITRAL, Decision on Jurisdiction; Chemtura Corporation cv Canada,UNCITRAL, Award, (02/08/2010); Methanex Corporation v. United States of America, UNCITRAL, Award on Jurisdiction and on the Merits, (03/08/2005).

12 The subject of interactions of law fields has become common in the study of international law. See for example: DELMASMARTY, Mireille. Les forces imaginantes du droit (II). Le pluralisme ordonné. Paris: Seuil, 2006. p. 303.; SEGGER, Marie-Claire Cordonier; GEHRING, Markus. W.; NEWCOMBE, Andrew. (Ed.). Sustainable development in world investment law. Alphen aan den Rijn: Kluwer Law International, 2011. p. 902.; HIRSCH, Mosche. Interactions
}

vein, many new international economic agreements which contain a chapter on investment protection also have relevant provisions on environmental protection. This can be seen in many of the recent free-trade agreements signed by a certain number of Latin American States. The free-trade agreement between the United-States and Peru for example highlights that investment protection provisions shall not be «construed to prevent a Party from adopting, maintaining, or enforcing any measure (...) that it considers appropriate to ensure that investment activity in its territory is undertaken in a manner sensitive to environmental concerns ${ }^{13}$ \%. Similar provisions can be found in agreements signed by Latin American States like Chile, Colombia, Honduras, Panama, Costa Rica with States like the United-States, Canada, Japan, Australia or Malaysia. On a more regional level, an economic partnership agreement signed between the European Union and the CARIFORUM innovates with a chapter on investors' behaviour which states that the State must take appropriate measures so as to ascertain that «[i]nvestors do not manage or operate their investments in a manner that circumvents international environmental or labour obligations arising from agreements to which the EC Party and the Signatory CARIFORUM States are parties. ${ }^{14} \gg$. These agreements have not yet received relevant interpretation or application and therefore, their effectiveness cannot as such be assessed. However, they do remain suitable examples corroborating this new conundrum of international investment law.

Building up an environmental defense. The most appropriate setting to examine the various aspects of

Between investment and non-investment obligations. In: MUCHLINSKI, Peter; ORTINO, Federico; SCHREUER, Christoph (Ed.). The Oxford handbook of international investment law. Oxford: Oxford University Press, 2008. p. 154-181; KOSKENNIEMI, Martti. Fragmentation du droit international: difficultés découlant de la diversification et de l'expansion du droit international. Geneva: Rapport du Groupe d'Étude de la Commission du droit international, 2006. p. 279.; MOLOO, Rahim; JACINTO, Justin. Environmental and health regulation: assessing liability under investment treaties. Berkley Journal of International Law, v. 29, n. 1, p. 101-165, 2011 VIÑUALES, Jorge. Foreign investment and the environment in international law: an ambiguous relationship. Research Paper, Geneva, n. 2, p. 1-74, 2010.; VIÑUALES, Jorge. Conflits normatifs en droit international: normes environnementales vs. protection des investissement. Le droit international face aux enjeux environnementaux, Paris, p. 407-428, 2010.

13 Free-trade agreement between the United-States and Peru (12/04/2006), article 10.11.

14 Economic Partnership Agreement between the European Union and the CARIFORUM, Bridgetown (15/10/2008), article 72 (c). 
this problematic interaction between investment law and environmental law remains the arbitral tribunals and their consideration of the matter. Indeed, if the raison d'être of their jurisdiction revolves around international investment law, they do not necessarily act in a close circuit, blind and deaf to non-investment considerations. Practically, they do accept arguments - normally brought forward by the States - framed on environmental protection. However, the admissibility of such arguments does not automatically imply that they will be decisive to build the tribunals' conclusions; their acceptation does not mean that a decision of nonsuit will be adopted against the investor claiming that an environmental regulation has, for instance, indirectly expropriated his investment. Still, practically, environmental issues appear under a specific format in investment arbitration: they act as a means of defense. They appear as what can be called, an 'environmental defense', used by the defendant State so as to justify that they cannot be held liable for protecting the environment; in the alternative, this defense aims at lowering the eventual compensation to be paid. Because of its specialisation, an arbitral tribunal in the ambit of international investment law is of course not the best forum to adjudicate environmental issues. The case law is not sufficiently developed and coherent to assert that it is an alternative forum. But despite their specialisation in investment litigation (I), arbitral tribunals do accept environmental arguments presented as a means of defense (II) which can, however, be barred by a claim grounded on the investor's legitimate expectations (III).

\section{THE SPECIALISATION OF ARBITRAL tRIBUNALS IN INVESTMENT LITIGATION}

Arbitral tribunals are expected to apply the law protecting investments. The protection available to international investors in international investment agreements is very tentacular. If they consider that a national measure is detrimental to their activities, they are blessed with a series of provisions enabling them to sue their host States ${ }^{15}$. The investor is, for example, protected against an unfair and unequal treatment, against discrimination related to nationality reasons or

15 See for example: OECD. Droit international de l'investissement: un domaine em movement: complément aux perspectives de l'investissement international. Paris: OECD, 2005. p. 175. against expropriatory measures ${ }^{16}$. In this sense, the legal questions set to arbitral tribunals have an already-fixed background. No novelty lies in this finding; just like a human rights court is specialised in human rights questions, an arbitral tribunal for investment matters is obviously expected to apply investment law. Many, if not the majority, of existing classical bilateral investment agreements rarely refer to non-investment matters. An arbitral tribunal is constituted on the basis of such types of agreements and it obviously prioritises questions based on investment protection. In the Santa Elena v. Costa Rica case, the tribunal stated that:

«While an expropriation or taking for environmental reasons may be classified as a taking for a public purpose, and thus may be legitimate, the fact that the Property was taken for this reason does not affect either the nature or the measure of the compensation to be paid for the taking. That is, the purpose of protecting the environment for which the Property was taken does not alter the legal character of the taking for which adequate compensation must be paid. The international source of the obligation to protect the environment makes no difference.

Expropriatory environmental measures-no matter how laudable and beneficial to society as a whole-are, in this respect, similar to any other expropriatory measures that a state may take in order to implement its policies: where property is expropriated, even for environmental purposes, whether domestic or international, the state's obligation to pay compensation remains. ${ }^{17} »$.

This does not necessarily denote that there is a bias in favour of the protection of private investors or that questions of public interests are forgotton or relegated to an inferior division ${ }^{18}$.

The arbitration system is voluntarily in disequilibrium in favour of the investors' protection. The overall system whereby the investor is always the claimant and the State, the defendant, indeed gives the appearance of a disequilibrium ${ }^{19}$. The latter does exist but

16 NEWCOMBE, Andrew; PARADELL, Luis. Law and practice of investment treaties: standards of treatment. Alphen Aan Den Rijn: Kluwer Law International, 2009. p. 147-398.

17 COMPAÑIA del desarrollo de Santa Elena S.A. v. Costa Rica, ICSID n. ARB/96/1, Award (17/02/2007), p. 71-72.

18 See for example: SORNARAJAH, Muthucumaraswamy. The settlement of foreign investment disputes. The Hague: Kluwer Law International, 2000, p. 9.

19 BEN HAMIDA, Walid. Le système actuel est-il déséquilibré 
is a voluntary one, accepted by States which knowingly sign and ratify investment agreements ${ }^{20}$. It actually and mainly belongs to the States to determine the degree of specialisation of arbitral tribunals because the former negotiate the investment agreements which provide for the latter's jurisdiction. Hence States have the required competence to frame such agreements as per their will and objectives. If they consider that environmental protection is paramount and that investors' activities should thereby be harnessed in this sense, they are in the best position to include environment protection provisions in the investment agreements they sign. The integration of environmental norms in international economic law can be an efficient means to contribute, at least partially, to the effectiveness of environment protection objectives $^{21}$. The above-mentioned free trade agreements perhaps constitute a first step to pave the way in this direction. Practically though, it is not always an easy achievement for developing States to successfully negotiate international agreements geared towards their interests. Indeed, they have a poor bargaining power in international negotiations. In 2006, for instance, Bolivia proposed a treaty project on equitable trade and cooperation to the United-States of America. Considering the economic disequilibrium between the two States, Bolivia suggested that a bilateral agreement should include, amongst others, provisions on poverty reduction, healthy environment, the promotion of agri-

en faveur de l'investisseur privé étranger et au détriment de l'Etat d'accueil?: table ronde. In: LEBEN, Charles. Le contentieux arbitral transnational relatif à l'investissement. nouveaux développement. Paris: L. G. D. J. 2006. p. 200; JUILLARD, Patrick. Le système actuel est-il déséquilibré en faveur de l'investisseur privé étranger et au détriment de l'Etat d'accueil?: table ronde. In: LEBEN, Charles. Le contentieux arbitral transnational relatif à i'investissement. nouveaux développements. Paris: L.G.D.J., 2006. p. 190-191; SORNARAJAH, Muthucumaraswamy. Power and justice: third world resistence in international law. Singapore Yearbook of International Law, v. 10, p. 32, 2006.; WALDE, Thomas. W. Procedural challenge in investment arbitration under the Shadow of the dual role of States: asymmetries and tribunals' duty to encure pro-actively, the equality of arms. Arbitration International, v. 26, n. 1, p. 15-16, 2010.

20 MONEBHURRUN, Nitish. Are Bilateral Investment Treaties Contemporary Unequal Treaties?. International Journal of Contemporary Laws, v. 1, n.1, 2012. Available on: <http://www.ijcl.co.in/ uploads/8/7/5/1/8751632/ijcl_vol.1_1_-_article_by_nitish.pdf $>$. 21 MONEBHURRUN, Nitish. Criticism on SDGs and presentation of the principle of integration as an international law instrument to contribute to sustainable development. In: OLIVEIRA, Carina Costa de; SAMPAIO, Rômulo da Rocha (Org.). Instrumentos jurídicos para a implementação do desenvolvimento sustentável: legal instruments for the implementation of sustainable development. Rio de Janeiro: FGV-Publication, 2012. p. 155-172. cultural and indigenous agriculture, sovereignty over natural ressources, principles of special and diffential treatment, the protection of biodiversity or of cultural diversity. The proposition was simply rejected by the United-States of America ${ }^{22}$. Some developing States have managed to negotiate bilateral investment treaties upholding their national interests but this remains an exception $^{23}$. In the majority of cases, investment tribunals have had to interprete and apply agreements which are purely focused on investment protection. But this did not prevent States from invoking non-investment related arguments to defend their position during the litigation process. In so doing, they have often relied on their national regulations on environment protection, or, on international environmental agreements. And in one way or the other, thinking that environmental protection measures are laden with legitimacy, they have presented them as a means of defense against the investors' claims, testing such arguments before arbitral tribunals.

\section{THE PROTECTION OF THE ENVIRONMENT AC- CEPTED AS A MEANS OF DEFENSE BY THE ARBITRAL TRIBUNALS.}

A means of defense strengthened by scientific expertise. Considering and studying environmental protection through the lenses of international investment law is of definite interest and has an unquestionable practical value. Various studies have been produced on the subject which is becoming more and more fashionable. This obviously has a consequence on the angles through which the matter is examined. Indeed, the cases whereby investment law interacts with environmental law are not innumerous and many of the conundrums, intricate as they are, have to a large extent already been enlightened. This contribution does not

\footnotetext{
22 FACH GOMEZ, Katia. Latin America and ICSID: David versus Goliath. Law and Business Review of the Americas, v. 17, p. 219-220, 2011.

23 See for example: The bilateral investment treaty between the United Kingdom and Vietnam (01/08/2002), Annex entitled « Exceptions to the grant of national treatment to investments and returns of investments of nationals or companies of the United Kingdom ", [available at: <http://www.unctad.org/sections / dite/iia/ docs/bits/uk_vietnam.pdf $>$ ]; Bilateral investm treaty between the United Kingdom and Panama (07/10/1983) [available at: http:// www.unctad.org/sections/dite/iia/docs/bits/uk_panama.pdf].
} 
necessarily seek to come up with new Gordian knots. Instead, it exhaustively tries to shed some new light on existing findings. Many investments made in Latin American States relate to sectors which are of environmental concern: waste management, mining, water or energy for instance. One of the means to strengthen an environmental defense in these sectors is to take stock from past cases where such defenses have proved successful. In this sense, an element which has a considerable influence in forging a solid environmental defense is the presentation of scientific reporting and expertise ${ }^{24}$. What appears behind this means of defense - apart from its strategical aspects - is a will by the State to promote and protect the national public interest of which it is the guarantor. In a way, this bears testimony of the presence of public interest questions in investment arbitration ${ }^{25}$. Even if international investment law mainly aims at the protection of private investors, the presence of and the reference to such questions is not anachronic; the arbitral procedure often concerns issues related to the fields of environmental protection ${ }^{26}$,

${ }^{24}$ See: VIÑUALES, Jorge. Foreign investment and the environment in international law: an ambiguous relationship. Research Paper, Geneva, n. 2, p. 30-34, 2010.

25 On these questions, see: CHOUDHURY, Barnali. Recapturing public power: is investment arbitration's engagement of the public interest contributing to the democratic deficit?. Vanderbilt Journal of Transnational Law, v. 41, n. 3, p. 791. 2008.; EL BOUDOUHI, Saïda. L'intérêt général et les règles substantielles de protection des investissements. Annuaire Français de droit international, v. 51, p. 542-563, 2005; SCHREUER, SCHREUER, Christoph, KRIEBAUM, Ursula. From individual to community interest in international investment law. In: FASTENRATH, Ulrich. et al. From bilateralism to community interest: essays in honour of judge Bruno Simma. Oxford: Oxford University Press, 2011. p. 1079; TEITELBAUM, Ruth. A look at the public interest in investment arbitration: is it unique? what should we do about it?. Berkley Journal of International Law Publicist, v. 5, p. 54-62, 2010.

26 Compañia del Desarrollo de Santa Elena, S.A., v. Costa Rica, ICSID n ${ }^{\circ}$ ARB/96/1, Award (17/02/2000); SD Myers v. Canada, UNCITRAL, Award partielle (13/12/2000); Metalclad Corporation v. Mexico, ICSID n ${ }^{\circ}$ ARB(AF) 97/1, Award (30/08/2000); Methanex v. USA, UNCITRAL, Award (30/08/2005); Ethyl Corp. \& Canada Ethyl Corp. v. Canada, UNCITRAL, Decision on Jurisdiction (24/06/1998); Chemtura Corporation v. Canada, UNCITRAL, Award (02/08/2010), human rights ${ }^{27}$, health ${ }^{28}$, cultural heritage ${ }^{29}$ or access to water and energy ${ }^{30}$. These elements are entrenched in the regulatory powers of States and they undeniably colour some phases of the litigation. It follows that, as an arbitral tribunal cannot impose a given line of defense, it has to listen to the parties' arguments so as to decide afterwards whether or not they are relevant and therefore, whether or not they are admissible. Normally, when environmental protection arguments are put forward, tribunals do unlock their jurisdictional space to accept such arguments and in some cases, much time is allocated to these questions ${ }^{31}$. Indeed, the environmental defense acts as a measure of the States' liability. Their aim is to seek a full exoneration by arguing that what the investor presents as a measure infringing the applicable investment agreement is simply a national environmental regulation which can also have been adopted in order to enforce an international environmental agreement. Still, to adopt a humble but at the same time practical position vis-à-vis this normative interaction leads to the following conclusion: international investment law has shown its permeability to environmental issues and considering the law as it exists, the highest consideration with which environmental norms can be dressed within the ambit of international investment law is that of an instrument of defense. Maybe it is as such that they should be sharpened and it is in this direction that they should be aligned for better efficiency in their use

27 Azurix v. Argentina, ICSID n ${ }^{\circ}$ ARB/01/12, Award (14/07/2006); Impregilo S.p.A. v. Argentina, ICSID n ${ }^{\circ}$ ARB/07/17, Award (21/06/2011); Continental Casualty Company v. Argentina, ICSID $n^{\circ}$. ARB/03/9, Award (5/09/2008); National Grid plc v. Argentina, UNCITRAL, Award (03/11/2008); Sempra Energy International v. Argentina, CRIDI n ${ }^{\circ}$. ARB/02/16, Award (28/09/2007); Siemens v. Argentina, ICSID n ${ }^{\circ}$ ARB/02/8, Award (06/02/2007); Suez, Sociedad General de Aguas de Barcelona, S.A. et Vivendi Universal, S.A. v. Argentina, ICSID $n^{\circ}$. ARB/03/19, Décision sur la responsabilité (30/07/2010); Aguas del Tunari S.A. v. Bolivia, ICSID nº. ARB/02/3 Pétition pour l'acceptation d'un amici curiae (29/08/2002).

28 SD Myers v. Canada, UNCITRAL, Award partielle (13/12/2000). 29 Southern Pacific Properties (Middle East) Ltd v. Egypt, ICSID $n^{\circ}$.ARB/84/3, Award (20/05/1992); Glamis Gold, Ltd. v. USA, UNCITRAL, Award (08/06/2009); Parkerings Companiet A.S. v. Lithuania, ICSID n ${ }^{\circ}$. ARB/05/8, Award (11/09/2007).

30 Suez, Sociedad General de Aguas de Barcelona, S. A. et Vivendi Universal, S.A. v. Argentina, ICSID $n^{\circ}$. ARB/03/19, Decision on Liability (30/07/2010),; Aguas del Tunari S. A. v. Bolivia, ICSID n ${ }^{\circ}$ ARB/02/3, Petition for the acceptation of amici curiae (29/08/2002).

31 See for example: Methanex Corporation v. United-States of America, UNCITRAL, Final Award on jurisdiction and on the merits (03/08/2005); ROBERT-CUENDET Sabrina. Protection de l'environnement et investissement étranger: les règles applicables à la dépossession du fait de la réglementation environnementale. Paris: Thèse, 2008. p. 322. 
and invocation. The scientific and technical expertise underpinning these arguments are also welcome in the same flow. Depending on the factual background of the case, the environmental defense could be used strategically with the sole aim of safeguarding the State's liability and in so doing, of avoiding or reducing the amount of any compensation due. The objective of environmental protection is not forgotton in this process; it is attained through a ricochet effect.

Scientific expertise must not be assessed technically by tribunals but used as elements of evidence. Arbitral tribunals can refer to or accept experts' opinions on any subject matter; they can ask the parties to a dispute to produce such expertise and they can ask for the presence of experts during the arbitration process. This is for example provided for at article 34 (2) (b) of the ICSID's rules of procedure ${ }^{32}$. Attention and caution, but also financial means, invested in environmental technical expertise can be decisive in the quest of convincing an arbitral tribunal ${ }^{33}$. Here, the state of development of the defendant State is, of course, very relevant. This will determine its capacity to invest in scientific studies just for the sake of arbitral proceedings. At the same time, it is true that the arbitrators might not always be technically equipped to fully understand a specialised environmental expertise ${ }^{34}$. In the Pulp Mill case before the International Court of Justice, considerable and dense scientific evidence had been brought by the parties ${ }^{35}$. This judgement was rendered with a joint dissenting opinion of Judges Simma and Al-Khasawneh and one of the reasons of their dissent was, they claimed, because of an inefficient methodology used by the Court to treat and process scientific studies brought before them ${ }^{36}$. It is indeed a question of methodology and it is clear that tribunals must not examine whether the expert reports are scientifically correct. It does not pertain to their role as tribunals and, in any case, they does not have the necessary technical competences and tools

\footnotetext{
32 The arbitral regulation is available at : http://icsid.worldbank. org/ICSID/ StaticFiles/basicdoc-fra/CRR_French-final.pdf

33 PAYNE, Cymie. Mastering the evidence: improving fact finding by international courts. Environmental Law, v. 41, p. 1191-1220, 2011. 34 VIÑUALES, Jorge. Foreign investment and the environment in international law: an ambiguous relationship. Research Paper, Geneva, n. 2, p. 31, 2010.

35 See: PAYNE, Cymie. Mastering the evidence: improving fact finding by international courts. Environmental Law, v. 41, p. 1198, 2011.

36 Pulp Mills on the River Uruguay (Argentina v. Uruguay), Judgment, I.v.J. Reports 2010, p. 109, \$2.
}

to do so; they are not expected to act as environmental experts. They must only view and accept such scientific findings as elements of evidence enabling them to reach a decision grounded in law $^{37}$. The Operational Rules for arbitration of disputes relating to natural resources and/or the environment of the Permanent Court of Arbitration has an interesting provision on this point. It states that the tribunal «may request the parties jointly or separately to provide a non-technical document summarizing and explaining the background to any scientific, technical or other specialized information which the arbitral tribunal considers to be necessary to understand fully the matters in dispute. ${ }^{38}$ \%. This approach helps to simplify technical data and process it for their optimal use by tribunals and can be considered as a productive step in the use of and in the access to scientific evidence. But even without a provision of this type, other tribunals have not been reluctant to consider scientific evidence.

To act as relevant and admissible evidence, the seriousness and the objectivity of the scientific expertise have to be examined. In one Methanex case, for example, the State of California had prohibited the use of 'MTBE ('methyl tertiary-butyl ether') in fuel production. The investor, Methanex, specialised in the production and distribution of methanol, claimed that the Californian measure had affected his activities, thereby violating the relevant NAFTA provisions on fair and equitable treatment, national treatment and expropriation $^{39}$. The State argued that the use of 'MTBE' was a threat to the environment as it could potentially pollute underground waters and drinkable water ${ }^{40}$. In so doing, it based it self on a scientif study examining the impact of 'MTBE' on human health and the environment; this study had been asked to the University of California ${ }^{41}$ and it indeed highlighted the risks inherent to the use

37 See for example: Chemtura Corporation v. Canada, UNCITRAL, Award (02/08/2010), \134-135; see also: VIÑUALES, Jorge. Foreign investment and the environment in international law: an ambiguous relationship. Research Paper, Geneva, n. 2, p. 61-62, 2010.

38 Permanent Court of Arbitration, Operational Rules for arbitration of disputes relating to natural resources and/or the environment, article 24(4).

39 Methanex Corporation v. United States of America, UNCITRAL, Final Award on Jurisdiction and on the Merits, (03/08/2005), see as from $\$ 26$.

40 Methanex Corporation v. United States of America, UNCITRAL, Final Award on Jurisdiction and on the Merits, (03/08/2005), $\$ 15$.

${ }^{41}$ Methanex Corporation v. United States of America, UNCITRAL, Final Award on Jurisdiction and on the Merits, (03/08/2005), Part III, chapter A. 
of the chemical component ${ }^{42}$. This expert opinion was favorably received by the tribunal which states that it:

«(...)accepts the UC Report as reflecting a serious, objective and scientific approach to a complex problem in California. Whilst it is possible for other scientists and researchers to disagree in good faith with certain of its methodologies, analyses and conclusions, the fact of such disagreement, even if correct, does not warrant this Tribunal in treating the UC Report as part of a political sham by California. In particular, the UC Report was subjected at the time to public hearings, testimony and peer-review; and its emergence as a serious scientific work from such an open and informed debate is the best evidence that it was not the product of a political sham engineered by California (...). Moreover, in all material respects, the Tribunal is not persuaded that the UC Report was scientifically incorrect: the Tribunal was much impressed by the scientific expert witnesses presented by the USA and tested under crossexamination by Methanex; and the Tribunal accepts without reservation these experts' conclusions. ${ }^{43}$ ».

The arbitrators must principally check the seriousness and objectivity of the expertise submitted before them. They will mostly focus on how the expertise was formulated, on how the scientific data was build rather than on what they technically contain. The parties' counsels are themselves first-class indicators of the scientific report and of the experts' eventual bias. They are free to proceed to their cross-examination during the proceedings in order to convince the tribunal of any suspicious flaw or superfluous findings. These debates help enlighten the value and objectivity of environmental expertise and are therefore use to forge the tribunal's conclusions. This framework is one whereby the scientific expertise on environmental questions is

42 Methanex Corporation v. United States of America, UNCITRAL, Final Award on Jurisdiction and on the Merits, (03/08/2005), Part III, Chapter A, \$S9-11. See for instance, $\$ 10$ : «It is clear that California water resources are being placed at risk by the use of MTBE in gasoline. MTBE has been detected in several water supply systems, which have shut down the contaminated sources, resorting to alternative supplies or treatment. Since both groundwater wells and surface water reservoirs have been contaminated, alternative water supplies may not be an option for many water utilities. If MTBE continues to be used at current levels and more sources become contaminated, the potential for regional degradation of water resources, especially groundwater basins will increase. Severity of water shortages during drought years will be exacerbated. California's water resources are placed at risk by the use of MTBE.». 43 Methanex Corporation v. United States of America, UNCITRAL, Final Award on Jurisdiction and on the Merits, (03/08/2005), Part III, Chapter A, $\$ 101$. brought forward by the defendant State willing to justify and explain the nature of an environmental regulation which has affected an investor's activities. The recourse to environmental specialists occurs after the investment has been made and when the State wished to defend the rational of its national regulation before an arbitral tribunal. However, in many cases, environmental studies and inspections are required before the investment is made. Under this configuration, the environmental defense may fail when faced to the legitimate expectations claims used often by the claimants.

\section{The ENVIRONMENTAL DEFENSE BARRED BY THE LEGITIMATE EXPECTATIONS CLAIMS.}

The environmental defense depends, in some cases, on the prior representations made by the State to the investor. In various cases, scientific environmental studies measure the environmental impacts of an investment, assess its conformity to the national environmental regulation and enable the State to distinguish between admissible and non-admissible investments ${ }^{44}$. Once an investor has passed the 'environment test', his activities are a priori considered as environment-friendly. If, ceteris paribus, the host State bars these activities in the future for reasons related to environmental protection, it might be making contradictory representations to the investor. This can potentially frustrate the legitimate expectations he had when he started business ${ }^{45}$. At the same time, such a position from the State can weaken the use of environmental imperatives as an instrument of defense. The tribunal constituted in the Parkerings case gave an interesting methodology to assess legitimate expectations. It highlighted that:

«The expectation is legitimate if the investor received an explicit promise or guaranty from the host-State, or if implicitly, the host-State made assurances or representation that the investor took into account in making the investment. Finally, in the situation where the host-State made no assurance or representation, the circumstances surrounding the conclusion of the agreement are decisive to determine if the expectation of

\footnotetext{
44 Many international investment agreements state that investments are to be made in conformity to the national laws and regulations.

45 WALDE, Thomas; KOLO, Abba. Environmental regulation, investment protection and 'regulatory taking' in international law. International and Comparative Law Quarterly, v. 50, n. 4, p. 819, 2001.
} 
the investor was legitimate. In order to determine the legitimate expectation of an investor, it is also necessary to analyse the conduct of the State at the time of the investment. ${ }^{46}$ \%.

The invocation of legitimate expectations is now common in the assessment of the fair and equitable treatment principle ${ }^{47}$ which is itself invoked in most cases $^{48}$. In this sense, an environmental inspection or study conducted by specialised experts and which acts as a condition for the establishment of a foreign private company in a given State can take the form of assurances or representations made by the State to the investor and relied upon by the latter for his investment: it is the assurance that the activity is conform to the national environmental regulation. The State's behaviour can, in this context, affect its environmental defense. In some cases against Mexico, the environmental defense was not considered as convincing because of the existence of prior representations made to the investor. In the TECMED case for instance, the intial permits which the investor had obtained to start and implement his activity of waste treatment had been controlled by the Parkerings-Compagniet AS v. Lithuania, ICSID nº. ARB/05/8,
Award (11/09/07), §331.
${ }_{47}$ Saluka Investments v. The Czech Republic, UNCITRAL Rules, Partial Award, 17 March 2006, \$-302; also, EDF (Services) Limited v. Romania, ICSID Case No.ARB/05/13, Award, 8 October 2009, \216; Suez, Sociedad General de Aguas de Barcelona, S.A. And Vivendi Universal, S.A. v. Argentina, ICSID No.. ARB/03/19, Decision on Liability, 30 July 2010, \\222-238; Ioannis Kardassopoulos v. Georgie, ICSID No. ARB/05/18, Award, 3 March 2010, S\$434-452; AES Summit Generation Ltd et AES-Tisza Eromu Kft. v. Hongrie, ICSID No. ARB/07/22, Award, 23 September 2010, \$S9.3.6-9.3.26; Enron Corporation and Ponderosa Assets, L.P. v. Argentina, ICSID No. ARB/01/3, Decision on Annulation, 30 July 2010, \$309; Alpha Projekholding GmbH v. Ukraine, ICSID No.ARB/07/16, Award, 8 November 2010, \$S420-422; EDF (Services) Limited v. Romania, ICSID Case No.ARB/05/13, Award, 8 October 2009, \$216, \$219, $\$ 245 / 6, \$ 298 ;$ BG Group Plc v. The Republic of Argentina, UNCITRAL, Final Award, 24 December 2007, §296; Tecnicas Medioambientales TECMED S.A. v. The United Mexican States, ICSID Case No. ARB (AF)/00/2, Award, 29 May 2003, \154; see also: CAZALA, Julien. Le traitement juste et equitable: transparence et protection des attentes légitimes de l'investisseur. Gazette du Palais, n. 349, p. 6, 15 dez. 2007; DOLZER, Rudolf; SCHREUER, Christoph. Principles of international investment law. Oxford: Oxford University Press, 2008. p. 134; MONEBHURRUN, Nitish; BARBOSA, Flavio Spaccaquerche. O tratamento e a proteção do investimento estrangeiro: a proteção do investimento estrangeiro. Revista Brasileira Dearbitragem, ed. especial, p. 107-144. set. 2011.

48 DOLZER, Rudolf; SCHREUER, Christoph. Principles of international investment law. Oxford: Oxford University Press, 2008, p.119; SCHREUER, Christoph. Fair and equitable treatment in arbitral practice. JWIT, v. 6, n. 3, p. 357, jun. 2005.
Hazardous Materials, Waste and Activities Division of the National Ecology Institute of Mexico and were considered as abiding to an Environmental Impact Declaration. Hence, the investment was made on the basis that the activities were respectful of the environment as acknowledged by the relevant Mexican authorities themselves; these circumstances had ascertained the investor's expectations ${ }^{49}$. He had been guaranteed that his activities, which had successfully passed all the environmental inspections ${ }^{50}$, were in conformity with the national environmental regulation ${ }^{51}$. However, the State refused to renew the inverstor's permit after some time arguing that the decision was underpinned by environmental protection objectives. In this case, the environmental defense is obviously very weak because it is difficult for the State to align coherent arguments: it cannot, on one hand, validate the investor's activities as 'environment-friendly' and, explain, on the other hand as it happened in TECMED, that it refused to renew his permit for environmental reasons ${ }^{52}$. Before the TECMED case, the Mexican State had been a party to a case with a similar background. The investment sector was the same: waste treatment and management. The investor, Metalclad, had obtained the required permits and his activities had not been considered as harmful for the environment ${ }^{53}$. Moreover scientific studies produced by the University of San Luis Petosi and by the Prosecutor's office for environmental protection had declared that the site of the investment was convenient for the treatment of hazardous wastes ${ }^{54}$. However, an ecological decree was later on adopted, thereby, characterising the site as a protected area ${ }^{55}$. Once again, the State's position was somehow contradictory and obviously, the environmental defense did not work. The tribunal in this case decided in favour of the investor ${ }^{56}$.

\footnotetext{
49 Técnicas Medioambientales Tecmed, S.A. v. Mexico, ICSID $\mathrm{n}^{\circ}$ $\mathrm{ARB}(\mathrm{AF}) / 00 / 2)$, Award (29/05/2003), \$150.

50 Técnicas Medioambientales Tecmed, S.A. v. Mexico, ICSID $\mathrm{n}^{\circ}$ $\mathrm{ARB}(\mathrm{AF}) / 00 / 2)$, Award (29/05/2003), \$124.

51 Técnicas Medioambientales Tecmed, S.A. v. Mexico, ICSID $\mathrm{n}^{\circ}$ $\mathrm{ARB}(\mathrm{AF}) / 00 / 2)$, Award (29/05/2003), \$124.

52 Técnicas Medioambientales Tecmed, S.A. v. Mexico, ICSID $\mathrm{n}^{\circ}$ $\mathrm{ARB}(\mathrm{AF}) / 00 / 2)$, Award (29/05/2003), \$145.

53 Metalclad Corporation v. Mexico, ICSID n ARB/AF/97/1, Award, (30/08/2000), \$\$29-33, \$43.

54 Metalclad Corporation v. Mexico, ICSID n ${ }^{\circ}$ ARB/AF/97/1, Award, (30/08/2000), \$44.

55 Metalclad Corporation v. Mexico, ICSID n ${ }^{\circ}$ ARB/AF/97/1, Award, (30/08/2000), \$59.

56 Metalclad Corporation v. Mexico, ICSID n ARB/AF/97/1, Award, (30/08/2000), \$111.
} 
The use of the environmental defense must be done in good faith. The invocation of the protection of the environment cannot be used as an excuse to escape from the obligations anchored in an investment agreement. The sole reference to environmental protection does not invalidade the State's other obligations.

The investor's duty of due diligence. However, the investor also bears some responsibility when it comes to measure the environmental impact of his activities and, in this sense, his legitimate expectations are not absolute. If the State has a duty of transparency and consistency, the investor must also embark on all his business decisions with due diligence ${ }^{57}$. He must therefore, on his side, undertake relevant research in order to assess the environmental nature of the investment site and he must also examine the environmental impacts of his activities ${ }^{58}$. This is even sometimes compulsory when investors are acting with the funding of International Financial Corporation ${ }^{59}$ or under the guarantee of the Multilateral Investment Guarantee Agency ${ }^{60}$. But, in any case, as part of his business planning the investor must, as stated by the arbitrators in the MTD v. Chile case, be fully aware of the applicable national regulations and of the environmental nature of the investment site ${ }^{61}$. Should he fail to be duly diligent with regards to such aspects of his investment, he cannot invoke any form of legitimate expectations and he is, at

\footnotetext{
57 Starret Housing Corp. v. Iran, 19 December 1983, 4 Iran-US CTR, 122; see also; MUCHLINSKI, Peter. Caveat investor?: the relevance of the conduct of the investor under the fair and equitable treatment standard. ICLQ, v. 55, p. 527-558, 2006; SALACUSE, Jeswald. W. The law of investment treaties. Oxford: Oxford University Press, 2010, p.234.

58 GEHRING, Markus W. Impact assessment of investment treatie. In: SEGGER, Marie-Claire Cordonier; GEHRING, Markus. W.; NEWCOMBE, Andrew. (Ed.). Sustainable development in world investment law.Alphen aan den Rijn: Kluwer Law International, 2011, p. 150.

59 IFC, IFC Sustainability Framework - Policy and Performance Standards on Environmental and Social Sustainability Access to Information Policy, 01/01/2012, 77p.; MATES, Carol M. Project finance in emerging markets-the role of the international finance corporation. Transnational Lawyer, v. 18, p. 165, 2004; MORGERA, Elisa. Significant trends in corporate environmental accountability: the new performance standards of the international finance corporation. Colorado Journal of International Environmental Law and Policy, v. 18, p. 159-160, 2007.

60 Operational Rules of MIGA, updated on the 04/02/2011, Annex B.

${ }_{61}$ MTD Equity Sdn. Bhd. \& MTD Chile S.A. v. Chile, ICSID n. ARB/01/7, Award (25/05/04), \$169; see also: Methanex Corporation v. United States of America, UNCITRAL, Final Award on Jurisdiction and on the Merits, (03/08/2005), Part IV, Chapter D, $\$ 9$.
}

least partially, responsible of any damage ${ }^{62}$. Obviously, in this case, he cannot expect the same level of compensation for the damage suffered ${ }^{63}$. In the present context, therefore, the reference to the investor's due diligence can be joined to the environmental defense. If the State must act in good faith, the investor must come to arbitration with clean hands.

\section{References}

BEN HAMIDA, Walid. Le système actuel est-il déséquilibré en faveur de l'investisseur privé étranger et au détriment de l'Etat d'accueil?: table ronde. In: LEBEN, Charles. Le contentieux arbitral transnational relatif à l'investissement. nouveaux développement. Paris: L. G. D. J. 2006.

CAZALA, Julien. Le traitement juste et equitable: transparence et protection des attentes légitimes de l'investisseur. Gazette du Palais, n. 349, p. 6, 15 dez. 2007.

CHOUDHURY, Barnali. Recapturing public power: is investment arbitration's engagement of the public interest contributing to the democratic deficit?. Vanderbilt Journal of Transnational Law, v. 41, n. 3, p. 775-832. 2008.

SEGGER, Marie-Claire Cordonier; GEHRING, Markus. W.; NEWCOMBE, Andrew. (Ed.). Sustainable development in world investment law. Alphen aan den Rijn: Kluwer Law International, 2011.

DELMAS-MARTY, Mireille. Les forces imaginantes $d u$ droit (II). Le pluralisme ordonné. Paris: Seuil, 2006.

DOLZER, Rudolf; SCHREUER, Christoph. Principles of international investment law. Oxford: Oxford University Press, 2008.

EL BOUDOUHI, Saïda. L'intérêt général et les règles substantielles de protection des investissements. $A n$ nuaire Français de droit international, v. 51, p. 542-563, 2005.

FACH GOMEZ, Katia. Latin America and ICSID: David versus Goliath. Law and Business Review of the Americas, v. 17, p. 195-221, 2011.

FITZMAURICE, Malgosia. International protection of

${ }^{62}$ VIÑUALES, Jorge. Foreign investment and the environment in international law: an ambiguous relationship. Research Paper, Geneva, n. 2, p. 71, 2010.

${ }^{63}$ MTD Equity Sdn. Bhd. \& MTD Chile S.A. v. Chile, ICSID nº. ARB/01/7, Award (25/05/04), \$243. 
the environment, R.C.A.D.I., v. 293, p. 9-488, 2001.

FRANCK, Suzanne. Development and outcome of investment treaty arbitration, Harvard International Law Journal, v. 50, n. 2, p. 201-255, 2009.

GAILLARD, Emmanuel. Anti-arbitration trends in Latin America, New York Law Journal, v. 239, n. 108, 5 jun. 2008.

GARCIA-BOLIVAR, Omar E. The surge of investment disputes: Latin America testing the international law of foreign investments. The Second Biennial General Conference Of the Asian Society of International Law, Tokyo, p. 1-9, aug. 2009.

GEHRING, Markus W. Impact assessment of investment treatie. In: SEGGER, Marie-Claire Cordonier; GEHRING, Markus. W.; NEWCOMBE, Andrew. (Ed.). Sustainable development in world investment law. Alphen aan den Rijn: Kluwer Law International, 2011.

HIRSCH, Mosche. Interactions Between investment and non-investment obligations. In: MUCHLINSKI, Peter; ORTINO, Federico; SCHREUER, Christoph (Ed.). The Oxford handbook of international investment law. Oxford: Oxford University Press, 2008.

JUILLARD, Patrick. Le système actuel est-il déséquilibré en faveur de l'investisseur privé étranger et au détriment de l'Etat d'accueil?: table ronde. In: LEBEN, Charles. Le contentieux arbitral transnational relatif à i'investissement. nouveaux développements. Paris: L.G.D.J., 2006.

KOSKENNIEMI, Martti. Fragmentation du droit international: difficultés découlant de la diversification et de l'expansion du droit international. Geneva: Rapport du Groupe d'Étude de la Commission du droit international, 2006.

MACHADO, Decio. Ecuador y la denuncia de los tratados bilaterales de inversión, CATDM, 07/12/2009. Available at: <http://www.cadtm.org/ Ecuador-y-ladenuncia-de-los $>$.

MATES, Carol M. Project finance in emerging marketsthe role of the international finance corporation. Transnational Lawyer, v. 18, p. 165, 2004.

MOLOO, Rahim; JACINTO, Justin. Environmental and health regulation: assessing liability under investment treaties. Berkley Journal of International Law, v. 29, n. 1, p. 101-165, 2011.
MONEBHURRUN, Nitish; BARBOSA, Flavio Spaccaquerche. $\mathrm{O}$ tratamento e a proteção do investimento estrangeiro: a proteção do investimento estrangeiro. Revista Brasileira Dearbitragem, ed. especial, p. 107-144. set. 2011.

MONEBHURRUN, Nitish. Are Bilateral Investment Treaties Contemporary Unequal Treaties?. International Journal of Contemporary Laws, vol. 1, no.1, 2012. Available on: <http://www.ijcl.co.in/uploads/8/7/5/1/8751632/ijcl_ vol.1_1_-_article_by_nitish.pdf $>$.

MONEBHURRUN, Nitish. Criticism on SDGs and presentation of the principle of integration as an international law instrument to contribute to sustainable development. In: OLIVEIRA, Carina Costa de; SAMPAIO, Rômulo da Rocha (Org.). Instrumentos jurídicos para a implementação do desenvolvimento sustentável: legal instruments for the implementation of sustainable development. Rio de Janeiro: FGV-Publication, 2012.

MORGERA, Elisa. Significant trends in corporate environmental accountability: the new performance standards of the international finance corporation. Colorado Journal of International Environmental Law and Policy, v. 18, p. 147-184, 2007. MORTIMORE, Michel, STANLEY, Leonardo. Justice denied: dispute settlement in latin america's trade and investment agreements, working group on development and environment in the Americas. Discussion Paper, n. 27, p. 2, oct. 2009.

MUCHLINSKI, Peter. Caveat investor?: the relevance of the conduct of the investor under the fair and equitable treatment standard. ICLQ, v. 55, p. 527-558, 2006.

NEWCOMBE, Andrew; PARADELL, Luis. Law and practice of investment treaties: standards of treatment. Alphen Aan Den Rijn: Kluwer Law International, 2009.

OECD. Droit international de l'investissement: un domaine em mouvement - complément aux perspectives de l'investissement international. Paris: OECD, 2005.

PAYNE, Cymie. Mastering the evidence: improving fact finding by international courts. Environmental Law, v. 41, p. 1191-1220, 2011.

RANCK, Suzanne. Development and outcome of investment treaty arbitration. Harvard International Law Journal, v. 50, n. 2, p. 202, 2009.

ROBERT-CUENDET Sabrina. Protection de l'environnement et investissement étranger: les règles ap- 
plicables à la dépossession du fait de la réglementation environnementale. Paris: Thèse, 2008.

SALACUSE, Jeswald. W. The law of investment treaties. Oxford: Oxford University Press, 2010.

SANDS, Philippe. Litigating environmental disputes: courts, tribunals and the progressive development of international environmental law: the policy framework for investment: the social and environmental dimensions, Global Forum on International Investment, OECD, p. 1-10, mar. 2008.

SCHREUER, Christoph, KRIEBAUM, Ursula. From individual to community interest in international investment law. In: FASTENRATH, Ulrich. et al. From bilateralism to community interest: essays in honour of judge Bruno Simma. Oxford: Oxford University Press, 2011.

SCHREUER, Christoph. Fair and equitable treatment in arbitral practice. JWIT, v. 6, n. 3, p. 357-387, jun. 2005.

SORNARAJAH, Muthucumaraswamy. The settlement of foreign investment disputes. The Hague: Kluwer Law International, 2000.

SORNARAJAH, Muthucumaraswamy. Power and justice: third world resistence in international law. Singapore Yearbook of International Law, v. 10, p. 19-57, 2006.

TIENHAARA, Kyla. Unilateral commitments to investment protection: does the promise of stability restrict environmental policy development?, Yearbook of International Environmental Law, v. 17, p. 133-167, 2006.

TEITELBAUM, Ruth. A look at the public interest in investment arbitration: is it unique? what should we do about it?. Berkley Journal of International Law Publicist, v. 5, p. 54-62, 2010.

VIÑUALES, Jorge. Foreign investment and the environment in international law: an ambiguous relationship. Research Paper, Geneva, n. 2, p. 1-74, 2010.

VIÑUALES, Jorge. Conflits normatifs en droit international: normes environnementales vs. protection des investissement. Le droit international face aux enjeux environnementaux, Paris, p. 407-428, 2010.

WALDE, Thomas. W. Procedural challenge in investment arbitration under the Shadow of the dual role of States: asymmetries and tribunals' duty to encure pro-actively, the equality of arms. Arbitration International, v. 26, n. 1, p. 15-16, 2010.

WALDE, Thomas; KOLO, Abba. Environmental regulation, investment protection and 'regulatory taking' in international law. International and Comparative Law Quarterly, v. 50, n. 4, p. 819, 2001. 
Para publicar na Revista de Direito Internacional, acesse o endereço eletrônico www.rdi.uniceub.br ou www.brazilianjournal.org.

Observe as normas de publicação, para facilitar e agilizar o trabalho de edição. 